\title{
Filling Gaps \\ The Reader of Harold Pinter's 'Monologue' (*)
}

\author{
Tahany M. Saeed El-Garhy (PHD.) \\ Department of English \\ Faculty of Arts - Beni-Suef University
}

\begin{abstract}
This paper attempts to study the role of the reader in one of Pinter's short memory plays, Monologue, using the theory of Wolfgang Iser concerning the gaps which the text leaves blank. Filling these gaps, the reader plays an important role in completing the text and reaching to the satisfaction which leads to a psychological equilibrium. The reader becomes a partner in the process of authoring a text.
\end{abstract}

This paper is divided into two parts; the first part is a general introduction to the theory of the reader in general, and the theory of filling gaps as introduced by Wolfgang Iser in his book entitled "The Act of Reading". The second part is an application of this theory on Harold Pinter's play entitled "Monologue". The paper raises the question of how Monologue is full of gaps and the reader tries to fill them. Monologue is a monodrama intended to portray the inner conflict of the narrator till the end. Through a long solo speech, the monologist is confined to his memories, unable to flee or even to communicate with the outside world. He becomes incapable of getting rid of his feeling of loneliness in an absurd society that deserted him, leaving him to undergo a feeling of futility, vacuity and a profound sense of void.

Key words: Pinter, Reader-response criticism, absurdity, monodrama, dramatic monologue, time and unconsciousness

${ }^{(*)}$ Bulletin of the Faculty of Arts Volume 79 Issue 6 July 2019 


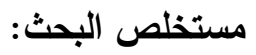

يهدف هذا البحث إلى إلقاء الضوء على دور القارئ في إحدى المسرحيات الصغرى

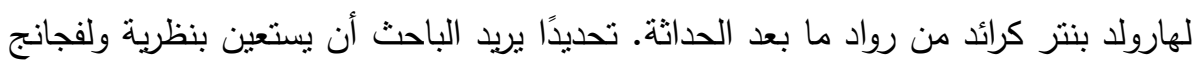

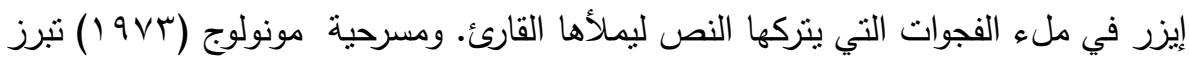
نمط درامي من الحوار وهو المونودراما التي يؤديها بطل واحد برسم لنا صورة من الذاكرة

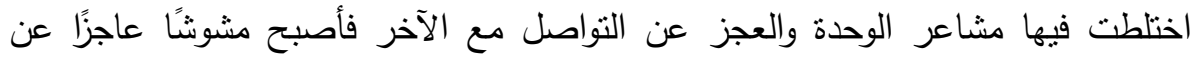
تحديد هويته ويشعر بعبنية وجوده. يينى بنتر مسرحيته معتمدًا على الصراع داخل شخصية الصنية

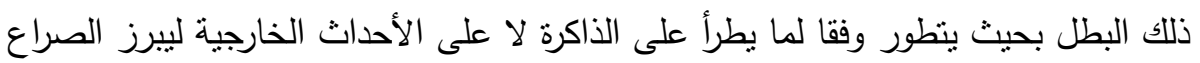

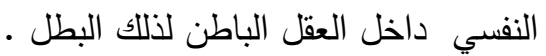
كلمات مفتاحية: بنتر - نظرية التلقي - العبث - المونودراما - المونولوج الدرامي

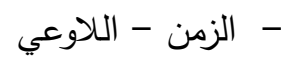

The one thing I try to do in all my books is to leave enough room in the prose for the reader to inhabit it. Because I finally believe it's the reader who writes the book and not the writer (Paul Auster, The Art of Hunger).

This paper will shed light on the role of the reader of Pinter's short memory television play Monologue. The role of the reader will be studied through Iser's theory of "filling gaps". The active involvement of the reader is necessary to present a detailed explanation to all the obscurities in the literary text. The notion of the reader and his interaction with the text goes back to Plato and Aristotle. According to Aristotle's Poetics:

Fear and Pity may be aroused by spectacular means; but they may also result from the inner structure of the piece, which is the better way, and indicates a superior poet (S. H. Butcher, 
XIV, P.49).

In classical times, the role of the reader was a secondary one compared to the superior role of the author. He is an ignored mediator unlike the author who is specially privileged. The whole interest is given to the author. In Plato's Ion, Socrates says: "The Muse inspires the poet, who in turn passes on this inspiration to the rhapsode, who produces an inspired emotional effect on the spectators....The Muse is the Magnet or loadstone; the poet is the first ring, the rhapsode is the middle ring, and the audience the last one (Ion, 533a, 536a-b)" (Habib, p. 23).

According to Plato, the reader is given a marginal role, the role of the passive receiver. However, Plato drew the attention to the reader, an attention which is to be developed to all the reader oriented theories that follow. This marginal role of the reader is altered to a major role with the appearance of the contemporary reader theorists who started in 1960s, and have dedicated themselves to study the reading process, or rather to concentrate on the outlook of the reader who is moved by the text to a certain meaning. They identify the reader as the most important ingredient in the reading process. The communication circuit begins with the reader's response and his participation in the imaginary world of the author. In her book, 'The Reader in the Text: Essays on Audience and Interpretation', Susan Rubin Suleiman states the notion that all the literary texts are:

devoted to the performance of the reading, the role of feeling, the variability of individual response, the confrontation, transaction, or interrogation between texts and readers, the nature and limits of interpretation-questions whose very formulation depends on a new awareness of the audience as an entity indissociable from the notion of artistic texts (p.4). 
Both the text and the reader are two related entities that cannot be separated. The reader is a primary contributor through his active participation in the text. He interprets the text because he finds vacant spaces he has to fill, a process without which the meaning becomes incomplete. He gives life to the text when he lives with the characters and feels their emotions. K. M. Newton writes: "A text can only come to life when it is read, and if it is to be examined, it must therefore be studied through the eyes of the reader" (p. 195). The interaction between the reader and the text has its own effect on the reader.

Wolfgang Iser views the reader as a major participant; conceives the hidden meaning and creates a perspective based on his personal experience and his own response. Iser points out that: "Reading is an activity that is guided by the text; this must be processed by the reader, who is then, in turn, affected by what he has processed" (The Act of Reading, p. 163). The reader who is affected by what he has read, tries to complete the blanks existed in the text. The blanks function as a means of communication. The reader's duty is to use his own ideas and imagination in order to grasp the meaning. Iser states the notion that:

Whenever the reader bridges the gaps, communication begins, The gaps function as a kind of pivot on which the whole text-reader relationship revolves. Hence the structured blanks of the text stimulate the process of ideation to be performed by the reader on terms set by the text (Ibid, p. 169).

In this respect, reading a text means filling the gaps that the author leaves open, by so doing the reader reveals the unspoken, and uncovers silence. The reader discloses the implied significance and accomplishes communication. Iser is concerned with "what a text can do to a reader, not with what a reader can do to a text" (Harland, p. 207). Unlike the other reader-response critics as Norman Holland, 
David Bleich or Stanley Fish, Iser believes that "one text is potentially capable of several different realizations, and no reading can ever exhaust the full potential, for each individual reader will fill in the gaps in his own way" (Ibid, p. 207). Each reader interprets the text according to his own experience.

Pinter says: "Meaning begins in the words, in the action, continues in your head and ends nowhere. There is no end to meaning" (Gordon, p. 8). Pinter sees that each reader generates meaning according to his own understanding of the literary text. Words in the text are basics of a series of meanings; the mind of the reader always finds new meanings occasioned by these words. The role of the reader is crucial in interpreting the words since "every literary text is built out of a sense of its potential audience, includes an image of whom it is written for: every work encodes within itself what Iser calls an 'implied reader', intimates in its every gesture the kind of 'addressee' it anticipates" (Eagleton, p. 84). The presence of the active reader is fundamental to the success of the literary text. The relationship between the text and the reader has a special form of communication that relies on the reader's experience.

The reader should be an informed reader to be able to convey meanings, and to "shift from the role of consumer to that of producer" (Eagleton, p. 137). The possibility of connecting the reader's own world of experience with what the text wants to convey, bridges the gaps and the communication occurs. What the reader produces is a kind of filling the gaps, clarifying the meaning and erasing obscurities. An indepth reading of the text unveils its opacities and removes its ambiguities. Iser remarks: "a second reading of a piece of literature often produces a different impression from the first" (Prospecting, p. 10). The reader renews his visions after each reading. Reading becomes an opportunity for more understanding and building up more meanings. 
In this paper, the reader attempts to interpret the author's ideas using his own imagination to bridge the unwritten implications and to understand what is the missing. Iser argues,

The significance of the work does not lie in the meaning sealed within the text, but in the fact that that meaning brings out what had previously been sealed within us. (Harland, p. 207)

Iser wants to say that the text is taken as an occasion through which the reader expresses meanings within himself, and reaches to solutions to his own problems whether they are psychological, social or philosophical._The reader tries to assemble the ideas provided by the text and to supply the missing blanks to create an integrated and meaningful whole. Iser writes: "The greater the number of blanks, the greater will be the number of different images built up by the reader" (The Act of Reading, 186). Hence, the important role of the reader in the process of the completion of the meaning of the text; the reader here is given a double task according to Iser: he has to hunt for the blanks and fill them up to complete the meaning. In this respect, the reader plays a great role in building up convincing images corresponding with the author's viewpoint. He endeavors to "unravel the dynamics of on-stage relationships in order to be able to understand the messages which are being sent out" (Leach, 15).

Readers can offer multiple possibilities for understanding the text. Each reader has his own vision in interpreting the text that differs from one to one according to his own experience, culture, historical background, mood, and psychology. The reception theory helps the reader to interact, and without this participation, there can be no performance since "the literary work has two poles, which we might call the artistic and the aesthetic: the artistic pole is the author's text and the aesthetic is the realization accomplished by the reader" (The Act of Reading, p. 21). Response relies on the interaction 
between the reader and the text. Reading is, therefore, a process of conveying what has been presented in the text. The reader achieves literary communication through understanding the author's message. He might ask himself how far and in what way the gaps are filled. In a conversation with Harold Pinter to the New York Times, he declares: "Naturally I'm very happy when the plays actually do communicate, when the audience enjoys them or finds them recognizable. It is naturally gratifying" ( Mel Gussow Dec. 5, 1971). It is natural for Pinter as an author to wait for the feedback of the audience. Pinter is aware of the important role of the reader in completing the meanings provided by the text. Pinter remarks:

The meaning of a play should emerge from the evolving image and that the dramatist should leave some of the clues in the crossword puzzle open. 'it's the audience that completes the play. (Michael Billington, p. 95)

Pinter sees that the reader builds an image based on his reading to complete the blank spaces that are left uncompleted in the text. In the same way, the American writer Paul Auster in The Art of Hunger claims: "The one thing I try to do in all my books is to leave enough room in the prose for the reader to inhabit it. Because I finally believe it's the reader who writes the book and not the writer" (qtd. in Billington, p. 95). The reader participates in writing the text according to Paul Auster. His share in authoring the text is not less important than the actual author. The text is always open to endless interpretations.

Monologue presents a psyche in a state of conflict, a narrator who fails to communicate with the outside world. Pinter says: "My plays are about what my titles are about" (qtd. in Gordon, p. 15). So the title is pivotal in reminding us of Robert Browning and his dramatic monologue that originated in the Victorian Age. Worth mentioning is the relation between Pinter's Monologue and 
Browning's dramatic monologues in My Last Duchess (1842) and The Ring and the Book (1868) in which Pinter does not directly identify the narrator's personality, but he trusts the reader's ability to make inferences from the given information. The character of the narrator becomes clear from his words and, more importantly, his inner conflict against himself, or against the society in which he lives.

The implied listener, in both the dramatic monologue and the monologue, keeps silent and does not involve in the action. He does not interrupt or comment. His silence gives the opportunity to the reader to interact, and to give feedback. The participation of the reader is anticipated and required to give meaning to the text and to clarify any mysteries. Lynne Truss says:

Robert Browning's My Last Duchess (1842) is the most oftencited example of a dramatic monologue. "That's my last Duchess painted on the wall, looking as if she were alive." My Last Duchess impeccably follows the rules of its genre; having a narrator, an occasion, an implied listener, an unfolding of narrative information, and the cunning, gradual revelation of the speaker's true nature. (Guardian, 3 May 2005)

Similar to Browning, Pinter presents a single narrator on the stage to relate his personal experience from memory. Based on the narrator's words, the reader can infer both the setting and the situation that drive the narrator to speak. Both the dramatic monologue and the monologue are based on an intellectual conflict that takes place in the unconscious mind of the narrator that is revealed through the narrator's interior monologue. Pinter benefited from Virginia Wolf and James Joyce who have the same view concerning the narrative consciousness. Michael Billington remarks in his book Harold Pinter that: "Pinter attempts in dramatic form something very close to what James Joyce and Virginia Woolf accomplished in the novel: the theatrical equivalent of the interior monologue" (p.191). They 
appreciate the important role of the narrator in joining the outward with the inward to paint a narrative consciousness of the given character. In his preface to 'The Theatre of Harold Pinter: Ten Selected Plays', Mohammed Enani writes:

The belief that there are qualitative gaps between fact and illusion, and that these gaps are artificial, dictated by the human mind, feelings and memory which may often betray him, does not hinder Pinter, and also Browning, from the belief in the presence of a fact, and struggling psychologically and mentally to find and catch it, in spite of his ability to elude, and the harmony that Pinter builds in his theatre between the attitudes of his characters, and inside his characters; between the viewpoints that may differ and contradict, forms a conflict of a new kind. This conflict may develop in the memory and its conditions not in the outside events only ( $p, 26$, my translation).

Enani sees that the dramatic monologue presents one situation in the narrator's life that may include all the elements of the conflict, and the reader hears about this conflict but never sees it. When the conflict takes place in the narrator's mind, as Enani sees, filling gaps takes place in the mind of the reader. The reader jumps in the mind of the narrator, trying to catch his fragmented thoughts to turn to some reasonable symmetry. This conflict develops only in the narrator's memory and not in the outside events. This is what Pinter did in his short memory play, Monologue, and in his long play, A Kind of Alska (1982).

Monologue is a monodrama written in "29 short fragments" (Gordon, p. 81), and has firstly been televised in about 20-minutes "on the BBC, 13 April 1973" (Ibid, p. 81). At the beginning of the play, Pinter conveys to the reader rather quickly a feeling of worry and stress that overwhelms the narrator. In a stage direction, Pinter makes it clear that: "Man alone in a chair. He refers to another chair, which is empty" (Monologue, p.121). The opening speech creates a picture of 
an unnamed man who sits alone in a chair to pour out memories from the past, directing his speech to an imagined friend existed in an empty chair. From the beginning of the play till the end, the narrator is talking only to himself, fixed in his chair. The action moves backward in time to recall events and memories happened in the past but are narrated in the present.

Pinter uses the vacant chair as a symbol of the narrator's spiritual vacancy which he tries to redeem by mere words. The narrator tries to fill this vacuum with words which do not achieve selfsatisfaction and thus he turns round with no reasonable conclusion. Thus, the empty chair refers obviously to the death of the soul and the decay of the spirit. Linda Ben-zvi writes:

In Monologue, however, the technique is unadulterated, with no ostensible receiver present; and the sign of absence - the chair - is placed on the stage, providing a visual metaphor of the self-reflexive nature of the character's speech. (Gordon, $\mathrm{p}$. 82)

Pinter focuses the spotlight on the empty chair to express the feeling of vacuity. The empty chair is also used to emphasize the spiritual vacuum and intensifies the atmosphere of separation. It is the focal point that raises many questions without giving clues, leaving the reader to guess the replies alone. The reader learns about the absent friend from comments made by the narrator, but the unseen friend never speaks a word in self-defense. By only presenting the narrator's opinion, Pinter succeeds to direct the reader's attention towards the narrator's subconscious mind to reveal his personality.

Pinter prefers to use an anonymous man to highlight the crisis of identity in the absurd theatre. The narrator is an absurd character who, as the play opens, is obviously derelict and unable to communicate with the outside world. He reflects "a picture of a contemporary man beaten down by the social forces around him, based on man's failure 
to communicate with other men" (Steven H. Gale, p.17). He represents his chaotic world with its emptiness, triviality and meaninglessness. His existential anxiety cages him inside his memories. Emptiness, especially of the world, seems to surround him, hindering him from any advance.

Martin Esslin discusses not only the theatrical technique of the absurd theatre and its mode of presentation but "locates the central impulse that has produced the theatre of the absurd in a conviction that life is senseless and meaningless - in short, that the human enterprise itself is absurd" (qtd. in Brooks, p.726). The absurdity of the human condition is reflected in Nietzsche's idea of the death of god which illustrates that the spiritual values began to give way for the material ones; the laws of profit overmastered the moral constitution of the society. Life itself is meaningless and communication among human beings has begun to break down. Esslin sees that Pinter is aware of the predicament of man in an absurd world that lacks ideals and spiritual certainty. According to Cleanth Brooks in his book, An Approach to Literature:

One can account for a good deal of the unmotivated action and the inconsequential answers by saying that many of the people represented in the theatre of the absurd are half mad or at least at the end of their tethers....A great many of the characters to be found in the theatre of the absurd are desperate and some not quietly but stridently so. (p. 727)

The previous quotation means that anxiety is a general mood inside man. The absurdity of man is the absurdity of life in general leaving people in a chaotic world. In a prolonged monologue; punctuated by ellipses, pauses and one full silence, a hesitant anonymous narrator is regulating the whole visible scene, begins the play:

I think I'll nip down to the games room. Stretch my legs. Have a game of ping-pong. What about you? Fancy a game? 
How would you like a categorical thrashing? I'm willing to accept any challenge, any stakes, any gauntlet you'd care to fling down. (Monologue, p. 121).

The narrator suggests to play a game of ping-pong if his absent friend agrees, so he says, "I think". The ironic situation is that the narrator is waiting for the approval of his absent friend to start the game. The reader may infer that the absent friend is always present in the narrator's memory and he directs the scene according to his will, despite his physical absence. The narrator utters a succession of insignificant questions that indicate his desperation. The questions are left unanswered to increase his state of anxiety and to prove the triviality of his speech. The reader tries to find answers for the questions to fill the gaps since "each work has a meaning and that the critic's quest for knowledge is an attempt to discover that meaning" (K. M. Newton, p. 99). It is the reader who tries to discover the implicit meaning in the text.

The blurred questions that are raised by the narrator do not lead to a resolution, but rather increases the confusion. The narrator says: "I keep busy in the mind, and that's why I'm still sparking, get it?" (Monologue, p. 126). The narrator tries to instigate the addressee to think, fill the gaps he leaves vacant. This is evident in the last question in the sentence "get it?", which means "did you understand?". The question is an attempt to search for more information about the nature of the narrator. The italicized word 'mind' is emphasized in the question to increase the reader's inquiry and to reflect his deep thinking. The main purpose of asking a question is to get information from the person being addressed but this is not achieved since the narrator is addressing an absent character. The unclear questions increase the obscurity and confirm the failure of communication. They also reflect the narrator's state of confusion and uncertainty. Some questions are repeatedly answered with the same questions: "Who was your best mate, Who was your truest mate?" (Ibid, p.122) or "Did anyone notice us? Did you see anyone looking at us?" (Ibid, p.124) The reader 
wonders if the repeated questions mean to increase the confusion or to add useful information. The text does not give a satisfactory answer to any of the questions that are raised by the narrator.

The inner conflict of the narrator is revealed from the outset; a feeling of "the loss of love, the isolation experienced in maturity, the desire for male bonding, and the slippages caused by the vagaries of memory and the imprecision of language" (qtd. in Gordon, p.82). A conflict that arises from an inner struggle between the narrator and his close friend after a quarrel over a girl. Rather, the identity of the narrator is revealed through his monologue with his unseen companion. The solo speech of the narrator expresses a hesitation and a feeling of anxiety which only dialogue can cure. His voice is a voice of a tortured man:

I was the best friend either of you ever had and I'm still prepared to prove it, I'm still prepared to wrap my braces round anyone's neck, in your defense. (Monologue, p. 123)

The previous extract sets up the time gap between the past and the present to indicate the distance between the two friends through using the repeated phrase "I'm still prepared" that is used in the present and its contrast with the grammatical form "I was" that is used in the past.

First, the narrator remembers his absent friend who moves to live alone. The narrator, is always in the present, remembering memories in the past: "You looked bold in black. The only thing I didn't like was your face, too white, the face, stuck between your black helmet and your black hair and your black motoring jacket, kind of aghast, blatantly vulnerable, veering towards pitiful" (Monologue, p. 121). The narrator draws an image from the memory of his absent friend who looks white and wears black clothes. The reader notices the repetition of the word "black" and its contrast with the word "white" to reflect Pinter's racial attitude. 
The treatment of important details as clothing, age and food has its symbolic reference in the play that leave gaps for the reader to fill. The preparation of "cocoa " in the play is repeated in most plays of Pinter. The narrator says: "Sitting there with your record player, growing bald, Beethoven, cocoa, cats. That really dates it. The cocoa dates it" (Monologue, p. 125). The reader stops before the word "bald" that is used to indicate that his absent friend has become an aged man, secluded, listening only to music and drinking cocoa, meeting no women. The cat is the only one to entertain and relief him in his loneliness. There is no movement in the action of the play since the monologue is narrated in the past. Lois Gordon writes:

Since there is no physical movement in the play, the speaker never leaving his chair, the only marks of time's passage are linguistic, and the familiar Pinteresque tensions between past and present are played out exclusively through language. (Pinter At 70, p. 82)

In this quotation the communication is achieved only in the narrator's mind. The narrator who chooses to live in the past, dares not to face his reality in the present with all its ailments. His interior monologue portrays his terrible loneliness and the impossibility of his communion with his friend. Their separateness is evident in the following extract:

I brought her to see you, after you'd pissed off to live in Notting Hill Gate. Naturally. They all end up there...Sitting there with your record player, growing bald, Beethoven, cocoa, cats. That really dates it. The cocoa dates it. It was your detachment was dangerous (Monologue, p.125).

The quotation means that the narrator accompanies the ebony girl to visit his close friend after moving to live in Notting Hill Gate. The substitute of names with pronouns has its significance in the play. 
Pinter refers to the monologist with the first person narrator "I" to help the reader to get into the narrator's distorted mind to reveal his thoughts. Pinter refers to the implied listener with the pronoun "you". The use of the pronoun "I" and "you" signifies the separateness and the steadily increasing psychic distance or hostility between the two friends.

Second, the narrator recalls the image of the black girl; the woman whom they both loved, and the cause of their struggle. The presentation of the theme of race, through the black girl, reflects Pinter's own awareness of his Jewishness. The idea of racism is recurrent in his plays. When the narrator moves to talk about the weather, he combines the clothes with the terrible weather to describe her dress: "The weather, so unpredictable. She'd put on a woolen dress because the morning was chilly, but the day had changed, totally, totally changed" (Monologue, p. 124). The repetition of the words "changed, totally, totally changed" is used as an indication of a seduction scene. The stop-gap ellipsis that cut the sentence "You jumped up....made her tea" (Ibid, 124) alerts the reader to think about the period of silence that happened between the time of jumping up until preparing tea for the girl and it also expresses a love scene. The romantic feelings between the two lovers are also illustrated in this extract:

As for me, I've always liked simple love scenes, the classic set-ups, the sweet...the sweet...the sweet farewell at Paddington Station. My collar turned up. (Monologue, p. 125)

The repetition of the italicized word 'sweet' for three times denotes his deep love for the girl and it is followed by a stop-gap ellipsis to indicate a deep thinking of her. The narrator intends to maintain contact without giving much information. This explains the needless use of repetition in the play through which Pinter conveys the 
narrator's unspoken thoughts aloud; his distorted mind, besides all his intentions, feelings, impressions and responses. The manipulation of certain repeated italicized words also alerts the reader's attention to focus on the meaning and to dig deep into the narrator's mind:

I keep busy in the mind...but can't you see, you bloody fool, that I can afford to do it, can't you appreciate the irony?...you can't miss the irony in the tone of voice! (Monologue, 126)

The quotation means that the narrator is busy thinking about their broken friendship._The ellipses that are used after the italicized word 'mind...' and before the pronoun '...you' are gaps that may reflect the narrator's hesitation during speaking. The three words 'mind, afford, voice' are consciously selected to be written in an italicized manner to make emphasis. There is a sensible repetition of the word 'irony'.

Contradictory emotions of love and hate, and peace and violence - completely overwhelming the narrator who is deserted from his close friend. His sick psyche is tormenting him, imagining falsely that once he is going to narrate his rotten memories; he frees himself of his pain and gets rid of his inner conflict. Accordingly, he will live in an inner peace. Thus, by reliving his memories; he feels comfort:

The thing I like, I mean quite immeasurably, is this kind of conversation, this kind of exchange, this kind of mutual reminiscence. (Monologue, p.122)

This quotation means that the narrator wants to evoke memories to maintain his communication. His feeling of distress comes from his feeling of loneliness that haunts him in daydreams. His pain is due to the unfriendly and icy feelings of his absent friend: "It was your detachment was dangerous. I knew it of course like the back of my hand" (Monologue, p. 125). The disinterest from the side of the absent 
friend is dangerous and leads to their separation.

The play reaches to the climax that the narrator lost his spiritual harmony and became anonymous when he lost his faith in God and abandoned his religion: "I no longer participate in holy ceremony. The crap is cut" (Monologue, p. 126). When the narrator lost his religious certainty, he no longer feels comfort. He fails to communicate with his close friend.

Pinter's characters interact in a peculiar way. They communicate through separation. The reader finds that the narrator withdraws from the present to the world of fancy and imagination; the world of past memories. Pinter applies pauses and silences to suggest the narrator's loneliness and separateness in an unreal world created by himself. Max Wysick argues: "rightly pauses and silences in Pinter's plays are largely a function of character relationships - or nonrelationships. Characters are not merely isolated, they are isolated from one another. Separation is a kind of interaction" (qtd. in Leslie Kane, p.146). The characters communicate in their silence.

Pinter uses silence as an important technique that relates the reader directly with the text. Silence creates gaps the reader has to fill. The (ellipses, the pauses, the direct reference to silence and the italics) are gaps imposed on the reader to imagine more than he could do if his reading is continuous. The unspoken words are important and expressive as the spoken ones to reveal implicit meanings. What is unspoken is felt by the reader who endeavors to fill the blanks:

What you are in fact witnessing is freedom. I no longer participate in holy ceremony. The crap is cut.

Silence.

You should had a black face, that was your mistake. You could have made a going concern out of it, you could have chalked it up in the book, you could have 
had two black kids.

Pause.

I'd have died for them.

Pause. (Monologue, p. 127)

In this quotation the narrator criticizes his friend who is white and loves a black girl because their relation may lead to black children. The reader concentrates on the unspoken words, and on the continual evasion to understand the unsaid. The reader uses his imagination to infer the reality out of this vagueness. Pinter once remarks: "You and I, the characters which grow on a page, most of the time we're inexpressive, giving little away, unreliable, elusive, evasive, obstructive, unwilling. But it's out of these attributes that a language arises" (Raby, p. 23). In his speech with Mel Gusso, Pinter utters these words:

The pause is a pause because of what has just happened in the minds and guts of the characters. They spring out of the text. They're not formal conveniences or stresses but part of the body of the action. I'm simply suggesting that if they play it properly, they will find that a pause-or whatever the hell it is-is inevitable. And a silence equally means that something has happened to create the impossibility of anyone speaking for a certain amount of time-until they can recover from whatever happened before the silence ( The New York Times, Dec. 5, 1971).

The quotation confirms the importance of the pause during the character's speech. Sometimes, the pause is unavoidable to depict the impossibility of communication between the characters but the active reader has the ability to read it because it is a written form of communication. The active reader is aware that "the unsaid in Pinter is as important as the said; and is frequently as eloquent.... The placing 
of the pauses, and their emotional significance, have always been meticulously considered....It is a very expressive form of dramatic speech" (Raby, p. 147-8).

The ellipses are used in purpose to conceal part of the narrator's interior monologue, and to show hesitation while speaking. The narrator intends to leave something unsaid for the reader to clarify: "Well...she did...can...could..." (Monologue, p. 124). Nicholas Ephram Ryan Daniels comments:

In a Pinter script, an ellipsis is used by the playwright to indicate slight hesitation. A pause was a much longer hesitation used by Pinter to more accurately depict the careful construction of an utterance. Generally, during a pause, the character is in the middle of a deep thought process and the use of this device helped to create tension and an unsettling atmosphere. A full-on silence, also known as a pregnant pause, is a dead stop during which no word is uttered because the character has encountered a conflict so absurd that they have nothing to say, and they are left in a completely different mental state from where they started (London Theatre Direct, May 14, 2018).

Ellipses are stop-gaps needed to be filled up. Ellipses are used to "replace the missing explanations, and seem to leave room on the page for readers to think about interaction" (Benejam). The anxiety of the narrator may cause a state of delay or silence during his speech, that makes him unable to differentiate between what is real and unreal or between the present and the past. Besides, his faltering may spring from a feeling of tension or pressure, and also from a deep stream of thinking. He is irresolute, or at a loss, or undecided to pour his thoughts unceasingly. His anxiety stops him from completing his speech uninterruptedly. 
The reader may come to the conclusion that the narrator's character is split into two entities; one represents the narrator; the other signifies the imaginary friend who is sitting on the empty chair. The narrator directs his speech to an implied listener as if he were talking to himself in a mirror. Pursuing the relationship between the two entities unveils the psychological problem of the narrator who suffers a feeling of anxiety and spiritual vacuum. Pinter has taken the reader into the narrator's sick mind to reveal his suffering. The reader is surprised with the two entities; one is a lively, caring of the details, and sensitive: "As for me, I've always liked simple love scenes, the classic set-ups, the sweet...the sweet...the sweet farewell at Paddington Station. My collar turned up" (Monologue, p. 125). While the other is a lifeless, passive and unresponsive one: "You often, I'll be frank, act as if you're dead" (Monologue, 123).

The play ends as it begins with the narrator's persistent longing for companionship. He draws a fragmented picture about black children who belongs to his absent friend to emphasize a desire for communion with the absent friend:

You could have had two black kids.

Pause.

I'd have died for them.

Pause.

I'd have been their uncle.

Pause.

I'm their uncle.

Pause.

I'm your children's uncle. 
Pause....

I love your children.

(Monologue, p. 127)

The reader tries to interpret the play that appears ambiguous despite its simplicity because the narrator draws a picture from the memory. Regardless of the play's brevity, it succeeds to disclose to the reader blurred memories, and fragmented thoughts which are so loosely connected that they seem chaotic. The reader tries to connect the memories which are not narrated in sequence but in a flashback through the monologist's eyes. The reader attempts to grasp the narrator's view of the past considering the reality that "there is often no certainty about memory, and even no absolutes concerning truth" (Raby, p. 146). The responsibility for organizing the fragments into a meaningful whole often falls to the reader, who thus becomes more actively involved in the text because "successful communication must ultimately depend on the reader's creative activity" (The Act of Reading, p. 112). The reader has to fill the void to reach a meaningful whole. When the reader gathers the fragmented story together, "his enjoyment begins when he himself becomes productive, i.e., when the text allows him to bring his own faculties into play" (Ibid, p. 108). The reader tries to interpret the embedded meanings.

\section{Conclusion}

This paper studies the role of the reader of Pinter's Monologue, in which the reader concerns to fill the blanks that are created by the Pinteresque technique, and to understand the events that are narrated in a flashback, applying Iser's critical theory of 'filling gaps'. The time gap between the narrator and his absent friend is not settled by pouring out his interior monologue, but rather the sense of isolation and loneliness is increased. The narrator appears as a hesitant 
traumatic character, incapable of facing the outside world. The reader tries to fill the gaps that are caused by the ellipses to reveal what is unwritten. He attempts to figure out the real meaning of the repeated italicized words or the pauses. The reader also tries to disclose the meaning of the blurred questions that are raised by the narrator. $\mathrm{He}$ tries to give meaning to the fragmented speech of the narrator or his chaotic impressions. So the whole burden falls on the reader's shoulder to create a meaningful whole and to come up with all the gaps.

No sooner had the narrator begun his monologue than he finds himself a prey of his past memories and a prisoner of his recollections. He recounts imaginary happenings as if they occur in the present. George H. Szanto in his book, 'Narrative Consciousness', points out: "A first person narrator usually tells a story as it happens in the past, in which case he has nothing to learn as the story progresses....Although the narratives are presented in the past tense, the senses of perception are constantly at work, as if the narrative were being lived at the moment" (Quoted in George Szanto). The whole action of the play happens in the narrator's sick psyche where he takes the reader back further and further into the past to follow his recollections using the flashback technique that is used in cinema. 


\section{Works Cited}

- Pinter, Harold, Plays in four volumes, (Contemporary Classics, Faber \& Faber Limited, London, 1996)

- Billington, Michael. 'Harold Pinter', (Faber \& Faber Limited, 1997)

- Brooks, Cleanth (ed.), Purser, John Thibaut (ed.), Warren, Robert Penn (ed.), 'An Approach to Literature', (Meredith Corporation, New York, 1967) p. 726

- Butcher, S. H. 'The Poetics of Aristotle', (London, Macmillan and Co., Limited, 1902)

- Eagleton, Terry. 'Literary Theory: An Introduction', (University of Minnesota Press, Minneapolis, London, 1983).

- Enani, M. 'The Theatre of Harold Pinter, Ten Selected Plays', translated and Introduced by M. Enani, EGBO, 2007)

- Gale, Steven H., 'Butter's Going Up: A Critical Analysis of Harold Pinter's work', (Durhum: Duke University Press,1977)

- Gordon, Lois. 'Pinter AT 70 A Casebook', (ROUTLEDGE, New York and London, 2001)

- Habib, Rafey. "A History of Literary Criticism from Plato to the Present", (Blackwell Publishing LTD, Oxford OX4 2DQ, UK, 2005)

- Harland, Richard. "Literary Theory from Plato to Barthes: An Introductory History", (Macmillan Press Ltd, London, 1999)

- Iser, Wolfgang. 'The Act of Reading: A Theory of Aesthetic Response', (The Johns Hopkins University Press Baltimore and London, 1978), p. 21

- -------------------. 'Prospecting from Reader Response to Literary Anthropology', (The Johns Hopkins University Press Baltimore and London, USA 1989), p. 10 
- Kane, Leslie. 'The Language of Silence on the Unspoken and the unspeakable in Modern Drama", (London and Toronto University Press, 1984)

- Leach, Robert. 'Theatre Studies, the Basics', (Routledge: Tylor and Francis Group, 2nd ed. 2008)

- Newton, K. M. 'Twentieth-Century Literary Theory', (St. Martin's Press, INC., USA, 1997)

- Raby, Peter. 'The Cambridge Companion to Harold Pinter' (ed), (Cambridge University Press, 2001)

- Suleiman, Susan Rubin ed. Crosman, Inge ed. 'The Reader in the Text: Essays on Audience and Interpretation', (Princeton University Press, New Jersey, 1980)

- Szanto, George H. 'Narrative Consciousness: Structure and Perception in the fiction of Kafka, Beckett, and Robbe-Grillet " (library of Congress, 1972)

- Benejam, Valerie. 'Charades and Gossip: The Minimalist Theatre of Joyce's Dubliners' (Journal of the Short Story in English, Autumn 2008)

- Billington, Michael. 'Harold Pinter.' (The Guardian, Saturday 27 December, 2008)

- Gussow, Mel. 'A Conversation [Pause] with Harold Pinter', (The New York Times', Dec. 5, 1971)

- Daniels, Nicholas Ephram Ryan. 'Pinter At the Pinter', (May 14, 2018) https://www.londontheatredirect.com/news/what-are-pinterpauses-and-other-pinteresque-devices

- Truss, Lynne. 'World of Interiors'. (The Guardian, Tue. 3 May, 2005) 